\title{
Growth and Yield of Sesame (Sesamum indicum L.) under the Influence of Planting Geometry and Irrigation Regimes
}

\author{
Asif Nadeem ${ }^{*}$, Shahabudin Kashani' ${ }^{2}$, Nazeer Ahmed ${ }^{2}$, Mahmooda Buriro ${ }^{3}$, Zahid Saeed ${ }^{1}$, \\ Fateh Mohammad ${ }^{2}$, Shafeeque Ahmed ${ }^{2}$ \\ ${ }^{1}$ Agriculture Extension, Panjgoor, Pakistan \\ ${ }^{2}$ Livestock Research Institute, Turbat, Pakistan \\ ${ }^{3}$ Sindh Agriculture University, Tandojam, Pakistan \\ Email: 'Shahabkashani64@gmail.com
}

Received 17 February 2015; accepted 18 April 2015; published 21 April 2015

Copyright (C) 2015 by authors and Scientific Research Publishing Inc.

This work is licensed under the Creative Commons Attribution International License (CC BY). http://creativecommons.org/licenses/by/4.0/

(c) (i) Open Access

\section{Abstract}

A field study to evaluate the "growth and yield of sesame (Sesamum indicum L.) under the influence of planting geometry and irrigation regimes" was carried out at Oilseeds Section, Agriculture Research Institute, Tandojam located at $\left(25^{\circ} 25^{\prime} 60^{\prime \prime} \mathrm{N}, 6^{\circ} 31^{\prime} 60^{\prime \prime} \mathrm{E}\right)$ during Kharif 2013 . The experiment was laid out in a three replicated randomized complete block design (RCBD) factorial, having net plot size $3 \times 3 \mathrm{~m}\left(9 \mathrm{~m}^{2}\right)$. The treatments comprised three planting geometry $(30 \times 20$ $\mathrm{cm}, 45 \times 15 \mathrm{~cm}$ and $60 \times 10 \mathrm{~cm}$ ) and three irrigation regimes ( 2 irrigations at 20 and 40 DAS, 3 irrigations at 20, 40 and 60 DAS and 4 irrigations at 20, 40, 60 and 80 DAS). The analysis of variance showed that all the planting geometry and irrigation regimes significantly $(P<0.05)$ affected growth and yield of sesame. Planting geometry of $45 \times 15 \mathrm{~cm}$ resulted in maximum branches plant $^{-1}(15.67)$, capsules plant ${ }^{-1}(38.00)$, seeds capsule ${ }^{-1}(51.44)$, seed weight plant $^{-1}(31.89 \mathrm{~g})$, seed index (2.83 g), biological yield (2301.23 kg.ha-1), seed yield (742.33 kg.ha-1) and harvest index (30.44\%), followed by planting geometry of $60 \times 10 \mathrm{~cm}$ in all the parameters. However, minimum growth and yield traits of sesame were recorded under planting geometry of $30 \times 20 \mathrm{~cm}$. Moreover, plant height was maximum $(99.89 \mathrm{~cm})$ under planting geometry of $30 \times 20 \mathrm{~cm}$. Among irrigation regimes, four irrigations $(20,40,60$ and 80 DAS) recorded maximum plant height $(103.33 \mathrm{~cm})$, branches plant ${ }^{-1}(16.44)$, capsules plant $^{-1}(41.22)$, seeds capsule ${ }^{-1}(54.56)$, seed weight plant ${ }^{-1}(33.22 \mathrm{~g})$, seed index $(2.92 \mathrm{~g})$, biological yield $\left(2321.21 \mathrm{~kg} \cdot \mathrm{ha}^{-1}\right)$, seed yield $(748.78$ $\mathrm{kg}^{\left.-\mathrm{ha}^{-1}\right)}$ and harvest index $(31.00 \%)$, followed by three irrigations $(20,40$ and 60 DAS) almost in all the traits. However, minimum growth and yield traits of sesame were recorded when crop was applied two irrigations (20 and 40 DAS). In case of interactive effects, the interaction of planting geometry of $45 \times 15 \mathrm{~cm} \times$ four irrigations $(20,40,60$ and 80 DAS) resulted in maximum attributes,

\footnotetext{
*Corresponding author.

How to cite this paper: Nadeem, A., Kashani, S., Ahmed, N., Buriro, M., Saeed, Z., Mohammad, F. and Ahmed, S. (2015) Growth and Yield of Sesame (Sesamum indicum L.) under the Influence of Planting Geometry and Irrigation Regimes. American Journal of Plant Sciences, 6, 980-986. http://dx.doi.org/10.4236/ajps.2015.67104
} 
particularly seed yield $\left(765.00 \mathrm{~kg} \cdot \mathrm{ha}^{-1}\right)$, whereas minimum traits were noted in the interaction of planting geometry of $30 \times 20 \mathrm{~cm} \times$ two irrigations (20 and 40 DAS). Furthermore, the results of four and three irrigations had non-significant differences with each other means not sharing the same letter differ significantly at 0.05 probability level. Hence, it is concluded that interaction of $45 \times 15 \mathrm{~cm}$ planting geometry and three irrigations $(20,40$ and $60 \mathrm{DAS})$ is conducive to produce maximum seed yield $\left(\mathrm{kg} \cdot \mathrm{ha}^{-1}\right)$ of sesame.

\section{Keywords}

Sesame, Planting Geometry, Irrigation Regimes, High Yield

\section{Introduction}

Sesame (Sesamum indicum L.) is the most conventional oilseed crop cultivated for its edible oil in the sub-continent. Sesame is known as the king of oil seeds due to the high oil content (50\% - 60\%) of its seed [1]. Sesame oil is used as foods (cooking and salad), medicine and soap manufacturing etc. Its seeds and young leaves are eaten as stews and soaps in Asia [2]. Til oil-cake is good feed for poultry, goat, sheep, fish and cattle [3].

Sesame crop is considered as a drought tolerant crop [4]. It was found in Africa and a small number in the Indo-Pakistan regions. According to archeological evidence, it was cultivated at Harappa in the Indus Valley between 2250 and $1750 \mathrm{BC}$, and a more recent charred sesame seeds had been found in MiriQalat and ShahiTump in the Makran region of Pakistan [5].

Pakistan is facing acute shortage of edible oil. Demand of edible oil in Pakistan is increasing with increase in population but production of edible oil is decreasing every year. The local production estimated at 0.680 million tons, meets only $24 \%$ of domestic requirement of edible oil while the remaining $76 \%$ is met through imports. Total availability from all sources is provisionally estimated at 1.749 million tons. Higher production of sesame may contribute towards edible oil and to meet country's requirement which may help in reducing the import [6].

The area under sesame cultivation in Sindh, Punjab, KPK and Balochistan during the year 2006 was 3.4, 75.1, 0.1 and 3.4 thousand hectares with the production of 1.4, 31.6, 0.1 and 2.0 thousand tons. The yield per hectare of sesame in Pakistan is low as compared to many other sesame growing countries of the world. The causes behind this setback are varied, which may include use of marginal land impure seed, low yielding varieties; improper sowing time, irrigation frequencies, fertilizer; and other cultural practices [7].

In Pakistan, sesame is grown in Kharif season (June-July). Low yield of sesame in Pakistan may be attributed to the lesser availability of good quality seed, sowing method (broadcast method), sowing time (early or late sowing) and less or over plant population [8]. Differential response of varieties to sowing dates showed that the yield of sesame was decreased with delay in sowing beyond third week of July [9]. To get high yield of a crop it is necessary to understand the interaction of crops with weather it plays important role in plant growth. Proper inter row and intra row spacing is of primary importance as it determines the proper plant population in the field. All these factors are also affected by the planting geometry of the crop. The environmental factors and management practices influence sesame productivity [10]. Suitable environmental conditions are necessary for optimum growth of crop and in field the crop yield also depends upon the row spacing between plants. Planting geometry is one of the major factors exploring the yield potential of a particular variety of oilseed crop [11]. The space available for individual plant growing in a community affects the yield and quality of produce. If space is more there may be less competition between plants and the chance of weed growth is definitely high. Whereas, space is less there may be high competition for growth factor like light, carbon-dioxide, moisture and nutrients among crop plants [12]. The establishment of an adequate and uniform crop stand is critical to achieve high seed yield. Seed yield of oilseed crop is a function of population density pods plant ${ }^{-1}$, seeds pod ${ }^{-1}$ and seed weight [13].

Due to decrease or increase in row space plant population of the crop varies and without optimum plant population one cannot get good crop yield. the higher yield of sesame was obtained when row to row distance was $30 \mathrm{~cm}$ and yield was decreased at $45 \mathrm{~cm}$ [14]. On reducing row space the plant height was increased but capsule plant $^{-1}$ decreased [15]. The recommended range of planting density for branched type is from 200 to 400 thousand plants ha ${ }^{-1}$. Five cultivation patterns of $30 \times 10,30 \times 15,30 \times 20,30 \times 25$ and $30 \times 30 \mathrm{~cm}$ for branched sesame varieties were evaluated. The results concluded that a seed yield increased from 417, 552 and 561 
$\mathrm{kg} \cdot \mathrm{ha}^{-1}$ while a row space increase from 10 to $20 \mathrm{~cm}$ and a wider row space increase to 25 and $30 \mathrm{~cm}$ caused a seed yield decrease to 510 and $395 \mathrm{~kg} \cdot \mathrm{ha}^{-1}$ [16]. The maximum plant height $(158.9 \mathrm{~cm})$, plants $\mathrm{m}^{-2}$ (60.33), capsules plant ${ }^{-1}$ (24.90), biological (4.003 Mg.ha ${ }^{-1}$ ) and seed yield $\left(0.857 \mathrm{Mg} \cdot \mathrm{ha}^{-1}\right)$, harvest index (21.42\%) and oil

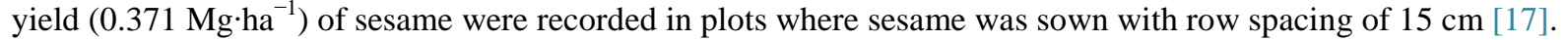

Irrigation optimization is a very important practice used in crop management, which could reduce irrigation water losses and maintain high yield. With increasing costs associated with irrigation, there is a need to ensure the maximum return from each unit of input applied. The need of crops for water is related to moisture sensitive periods. If moisture sensitive periods could be identified for wheat crop under field conditions, it would have important implications for irrigation practice [18]. Irrigation scheduling is important for achieving the higher crop yields. Irrigation frequency is the decision of when and how much water to apply to a field. Its purpose is to maximize irrigation efficiencies by applying the exact amount of water needed to replenish the soil moisture to the desired level. Irrigation scheduling saves water and energy, and all irrigation scheduling procedures consist of monitoring indicators that determine the need for irrigation. The purpose of irrigation scheduling is to determine the exact amount of water to apply to the field and the exact timing for application. The amount of water applied is determined by using a criterion to determine irrigation need and a strategy to prescribe how much water to apply in any situation [19].

Water depletion is estimated from root zone and effect on sesame yield and water consumptive use. In a recent study, the predictions for moisture stress suggested applying five irrigations to sesame [20]. Applying six irrigations gave the highest values of yield and its attributes, whereas the lowest values were recorded from applying five irrigations and skipping one at the beginning of flowering [21]. Whereas, Davut et al. (2007) achieved highest sesame yield under 6 days interval of irrigation and lowest when irrigation applied at 24 days interval [22]. Keeping in view the facts stated above, a study was designed under the agro-ecological conditions of Tandojam.

\section{Materials and Methods}

The field study was carried out at Oilseeds Section, Agriculture Research Institute, Tandojam $\left(25^{\circ} 25^{\prime} 60^{\prime \prime} \mathrm{N}\right.$, $68^{\circ} 31^{\prime} 60^{\prime \prime E}$ ) during Kharif 2013. The experiment was laid out into a three replicated randomized complete block design (RCBD) factorial, having net plot size $3 \mathrm{~m} \times 3 \mathrm{~m}\left(9 \mathrm{~m}^{2}\right)$. Planting geometry and irrigation regimes were maintained as per treatments, whereas all other inputs and cultural operations were adopted as per the recommendations of Oilseeds Section, Agriculture Research Institute, Tandojam. The treatments comprised of three planting geometry $(30 \times 20 \mathrm{~cm}, 45 \times 15 \mathrm{~cm}$ and $60 \times 10 \mathrm{~cm})$ and three irrigation regimes (2 irrigations at 20 and 40 DAS, 3 irrigations at 20, 40 and 60 DAS and 4 irrigations at 20, 40, 60 and 80 DAS).

\subsection{Experimental Soil}

Soil condition of experimental area was clay loam in texture, non-saline (EC 0.14 to $0.68 \mathrm{dS} \cdot \mathrm{m}^{-1}$ ) in nature, slightly alkaline in reaction ( $\mathrm{pH} 7.24$ to 7.75$)$, calcareous $\left(\mathrm{CaCO}_{3} 9.5 \%\right)$, low in organic content $(0.62 \%$ $0.86 \%$ ), total nitrogen content varied from $0.03 \%-0.06 \%$ and available phosphorus ranged from 6.8 to 9.2 $\mathrm{mg} \cdot \mathrm{kg}^{-1}$. However, soil of the experimental area was marginal in extractable potassium $\left(60-110 \mathrm{mg} \cdot \mathrm{kg}^{-1}\right)$ content.

\subsection{Land Preparation}

For preparation of fine seedbed, disc harrow was run to open and pulverize the soil, and the land was leveled and planked. After soaking dose, when the land came in condition, the cultivator was used, followed by rotavator. The treatments were managed in such a way to separate each treatments and replications easily, and the channels and bunds were developed to facilitate the irrigation water application and interculturing.

\subsection{Sowing Time and Method}

The seed of sesame variety S-17 was grown on June 2013 with the help of single row hand drill. The row to row spacing of $75 \mathrm{~cm}$ and plant to plant distance $22.5 \mathrm{~cm}$ was maintained apart. Seed rate $5 \mathrm{~kg} / \mathrm{hac}$.

\subsection{Fertilizer}

Nitrogen and phosphorus fertilizers were applied at recommended rate of Full dose of phosphorus in the form of 
DAP, whereas half dose of Nitrogen in the form of Urea were applied at the time of sowing. Remaining half dose of Nitrogen was applied at the time of first irrigation.

\subsection{Weeding}

The weeds were controlled by interculturing at $1^{\text {st }}$ and $2^{\text {nd }}$ irrigations.

\subsection{Procedure for Recording Observations}

1) Plant height (cm): Plant height was recorded at maturity of crop using measurement tape from bottom to tip of the randomly selected five plants in each plot and was averaged in $(\mathrm{cm})$.

2) Branches plant ${ }^{-1}$ : Branches in randomly selected five plants were counted and accordingly average plant ${ }^{-1}$ was worked out in each treatment.

3) Capsules plant ${ }^{-1}$ : The capsules randomly selected five plants were counted in each plot and averaged plant ${ }^{-1}$ basis.

4) Seeds capsule ${ }^{-1}$ : At maturity, the capsules from the randomly selected five plants were threshed and number of seeds in each capsule was counted and averaged.

5) Seed weight plant ${ }^{-1}(\mathrm{~g})$ : At maturity, the seed obtained from all the randomly selected five plants were weighed and calculated on the basis of number of plants threshed to get average weight of seeds plant ${ }^{-1}(\mathrm{~g})$.

6) Seed index (1000 seeds weight, g): One thousand seeds from the seed lot threshed in each plot was collected and weighed to obtain seed index in (g).

7) Biological yield (kg·ha ${ }^{-1}$ ): At maturity, the sesame crop in each plot was harvested; weighed and biological yield was converted to $\mathrm{kg} \cdot \mathrm{ha}^{-1}$.

8) Seed yield $\left(\mathbf{k g} \cdot \mathbf{h a}^{-1}\right)$ : At maturity, the sesame crop in each plot was harvested and threshed, and yield ha ${ }^{-1}$ was calculated by the following formula:

$$
\text { Seed yield ha }{ }^{-1}(\mathrm{~kg})=\frac{\text { Seed yield } \text { plot }^{-1}(\mathrm{~kg})}{\text { Plot size }\left(\mathrm{m}^{2}\right)} \times 10000
$$

9) Harvest index (\%): Harvest index is the ratio between seed yield and biological yield.

Harvest index (\%) was calculated by the following formula.

$$
\text { Harvest index }(\%)=\frac{\text { Seed yield }\left(\mathrm{kg} \cdot \mathrm{ha}^{-1}\right)}{\text { Biological yield }\left(\mathrm{kg} \cdot \mathrm{ha}^{-1}\right)} \times 100
$$

\subsection{Statistical Analysis}

The collected data were subjected to statistical analysis using MSTAT-C. The differences among the treatments means were compared by the least significant difference (LSD), where necessary (Russel and Eisensmith, 1983).

\section{Result and Discussions}

The results of this study showed that all the levels of planting geometry and irrigation regimes affected significantly $(\mathrm{P}<0.05)$ the growth and yield of sesame. Planting geometry of $45 \times 15 \mathrm{~cm}$ resulted in maximum branches plant ${ }^{-1}$ (15.67), capsules plant ${ }^{-1}$ (38.00), seeds capsule ${ }^{-1}$ (51.44), seed weight plant ${ }^{-1}$ (31.89 g), seed index (2.83 g), biological yield (2301.23 kg.ha $\left.{ }^{-1}\right)$, seed yield $\left(742.33 \mathrm{~kg} \cdot \mathrm{ha}^{-1}\right)$ and harvest index (30.44\%), followed by planting geometry of $60 \times 10 \mathrm{~cm}^{-1}$ with branches plant ${ }^{-1}(12.22)$, capsules plant ${ }^{-1}$ (35.22), seeds capsule $^{-1}$ (47.00), seed weight plant ${ }^{-1}$ (27.11 g), seed index (2.36 g), biological yield (2208.58 kg.ha $\left.{ }^{-1}\right)$, seed yield $\left(712.44 \mathrm{~kg} \cdot \mathrm{ha}^{-1}\right)$ and harvest index $(28.33 \%)$. However, minimum growth and yield traits of sesame were recorded under planting geometry of $30 \times 20 \mathrm{~cm}$ (Table 1). Moreover, plant height was maximum $(99.89 \mathrm{~cm})$ under planting geometry of $30 \times 20 \mathrm{~cm}$. Planting geometry affected the plant height of sesame significantly. The crop which was sown at planting geometry of $30 \times 20 \mathrm{~cm}$ produced significantly taller plants than at other planting geometry. The increase in plant height in case of $30 \times 20 \mathrm{~cm}$ planting geometry may be due to narrow row spacing, when the number of plants $\mathrm{m}^{-2}$ increases then the competition for light increases and plant grows taller to intercept maximum light. These results are in accordance with the findings of Caliskan et al. (2004) who reported taller plants with increase in plant population. The crop which was at planting geometry of $60 \times 10$ 
cm produced significantly shortest plants [23]. The crop which was sown at planting geometry of $45 \times 15 \mathrm{~cm}$ produced significantly maximum branches plant ${ }^{-1}$, capsules plant ${ }^{-1}$, seeds capsule ${ }^{-1}$, seed weight plant ${ }^{-1}$, seed index (g), biological yield, seed yield and harvest index. This may be due to optimum plant population and had more chance to get nutrients. These results are in line with those of El-Naim et al. (2010) who demonstrated that increasing plant density significantly decreased the number of branches plant ${ }^{-1}$, the number of capsules plant ${ }^{-1}$ and seed yield plant ${ }^{-1}$, decreased the number of branches plant ${ }^{-1}$, the number of capsules plant ${ }^{-1}$ and seed yield plant $^{-1}$, but led to increased seed yield per unit area [24]. Similarly, Tahir et al. (2012) revealed that maximum plant height, plants $\mathrm{m}^{-2}$, capsules plant ${ }^{-1}$, biological, and seed yield, harvest index and oil yield were recorded in plots where sesame was sown at 15th June with row spacing of $15 \mathrm{~cm}$ [17]. In another study, Roy et al. (2009) reported that higher yield of sesame was obtained when row to row distance was $30 \mathrm{~cm}$ and yield was decreased at $45 \mathrm{~cm}$ [14].

As it is shown in Table 2, Four irrigations (20, 40, 60 and 80 DAS) recorded maximum plant height (103.33 $\mathrm{cm})$, branches plant ${ }^{-1}(16.44)$, capsules plant ${ }^{-1}(41.22)$, seeds capsule ${ }^{-1}$ (54.56), seed weight plant ${ }^{-1}(33.22 \mathrm{~g})$, seed index (2.92 g), biological yield $\left(2321.21 \mathrm{~kg} \cdot \mathrm{ha}^{-1}\right)$, seed yield $\left(748.78 \mathrm{~kg} \cdot \mathrm{ha}^{-1}\right)$ and harvest index $(31.00 \%)$, followed by three irrigations (20, 40 and 60 DAS) with $101.78 \mathrm{~cm}^{-1}$ plant height, 15.33 branches plant ${ }^{-1}, 40.22$ capsules plant ${ }^{-1}, 52.78$ seeds capsule ${ }^{-1}, 32.11$ g seed weight plant $^{-1}$, 2.77 g seed index, biological yield (2292.62 $\left.\mathrm{kg} \cdot \mathrm{ha}^{-1}\right)$, seed yield $\left(739.56 \mathrm{~kg} \cdot \mathrm{ha}^{-1}\right.$ ) and harvest index (30.11\%). However, minimum growth and yield traits of sesame were recorded when crop was applied two irrigations (20 and 40 DAS) [25].

Table 3 shown the analysis of variance regarding plant height and branches plant ${ }^{-1}$ highly significant $(\mathrm{P}<$ 0.01 ) effect of planting geometry irrigation regimes. The result regarding capsules plant ${ }^{-1}$, seeds capsule ${ }^{-1}$, weight plant ${ }^{-1}$, seed index, biological yield, seed yield and harvest index their analysis of variance showed highly significant $(\mathrm{P}<0.01)$ effect of planting geometry and irrigation regimes, whereas non-significant $(\mathrm{P}>$ 0.05) effect of their interaction [25].

Table 1. Means of growth and yield traits of sesame under planting geometry.

\begin{tabular}{|c|c|c|c|c|c|c|c|c|c|}
\hline $\begin{array}{l}\text { Planting } \\
\text { geometry }\end{array}$ & $\begin{array}{l}\text { Plant height } \\
\text { (cm) }\end{array}$ & $\begin{array}{c}\text { Branches } \\
\text { plant }^{-1}\end{array}$ & $\begin{array}{c}\text { Capsules } \\
\text { plant }^{-1}\end{array}$ & $\begin{array}{c}\text { Seed } \\
\text { capsules }^{-1}\end{array}$ & $\begin{array}{l}\text { Seed weight } \\
\text { plant }^{-1}(\mathrm{~g})\end{array}$ & $\begin{array}{l}\text { Seed index } \\
\text { (g) }\end{array}$ & $\begin{array}{c}\text { Biological yield } \\
\left(\mathrm{kg} / \mathrm{ha}^{-1}\right)\end{array}$ & $\begin{array}{c}\text { Seed yield } \\
\left(\mathrm{kg}^{\prime} \mathrm{ha}^{-1}\right)\end{array}$ & $\begin{array}{c}\text { Harvest } \\
\text { index (\%) }\end{array}$ \\
\hline $30 \times 20 \mathrm{~cm}$ & 99.89 a & $12.22 \mathrm{c}$ & 35.22 c & $47.00 \mathrm{~b}$ & $27.11 \mathrm{c}$ & $2.36 \mathrm{c}$ & 2208.58 b & $712.44 \mathrm{~b}$ & 28.33 c \\
\hline $45 \times 15 \mathrm{~cm}$ & $96.56 \mathrm{~b}$ & 15.67 a & 38.00 a & $51.44 \mathrm{a}$ & 31.89 a & $2.83 \mathrm{a}$ & 2301.23 a & 742.33 a & 30.449 a \\
\hline $60 \times 10 \mathrm{~cm}$ & 92.44 c & $13.67 \mathrm{~b}$ & 36.44 b & 49.56ab & 30.78 a & $2.61 \mathrm{~b}$ & $2242.68 \mathrm{~b}$ & $723.44 \mathrm{~b}$ & 29.44 b \\
\hline
\end{tabular}

Note: Means with same letter in each column are not significantly different at a 5\% probability level.

Table 2. Means of growth and yield traits of sesame under different irrigation regimes.

\begin{tabular}{|c|c|c|c|c|c|c|c|c|c|}
\hline $\begin{array}{c}\text { Irrigation } \\
\text { regimes }\end{array}$ & $\begin{array}{c}\text { Plant } \\
\text { height }(\mathrm{cm})\end{array}$ & $\begin{array}{l}\text { Branches } \\
\text { plant }^{-1}\end{array}$ & $\begin{array}{c}\text { Capsules } \\
\text { plant }^{-1}\end{array}$ & $\begin{array}{c}\text { Seed } \\
\text { capsules }^{-1}\end{array}$ & $\begin{array}{l}\text { Seed weight } \\
\text { plant }^{-1}(\mathrm{~g})\end{array}$ & $\begin{array}{l}\text { Seed index } \\
\text { (g) }\end{array}$ & $\begin{array}{l}\text { Biological yield } \\
\left(\mathrm{kg}^{\prime} \mathrm{ha}^{-1}\right)\end{array}$ & $\begin{array}{l}\text { Seed yield } \\
\left.\text { (kg }^{-h^{-1}}\right)^{-}\end{array}$ & $\begin{array}{c}\text { Harvest } \\
\text { index (\%) }\end{array}$ \\
\hline $\begin{array}{l}2 \text { irrigations (20 } \\
\& 40 \text { DAS) }\end{array}$ & $83.78 \mathrm{c}$ & $9.78 \mathrm{c}$ & 28.22 c & $40.67 \mathrm{~b}$ & $24.44 \mathrm{~b}$ & $2.11 \mathrm{c}$ & 2138.66 b & 689.89 b & 27.11c \\
\hline $\begin{array}{c}3 \text { irrigations } \\
\text { (20, } 40 \& 60 \\
\text { DAS) }\end{array}$ & $101.78 \mathrm{~b}$ & $15.33 \mathrm{~b}$ & $40.22 \mathrm{a}$ & 52.78 a & 32.11 a & $2.77 \mathrm{a}$ & 2292.62 a & 739.56 a & 30.11 b \\
\hline $\begin{array}{c}4 \text { irrigations } \\
\text { (20, 40, } 60 \text { \& } \\
80 \text { DAS) }\end{array}$ & $103.33 \mathrm{a}$ & 16.44 a & $41.22 \mathrm{a}$ & 54.56 a & 33.22 a & $2.92 \mathrm{a}$ & $2321.21 \mathrm{a}$ & 748.78 a & $31.00 \mathrm{a}$ \\
\hline
\end{tabular}

Note: Means with same letter in each column are not significantly different at a 5\% probability level.

Table 3. Analysis of variance for growth and yield parameters.

\begin{tabular}{|c|c|c|c|c|c|c|c|c|c|c|}
\hline $\begin{array}{l}\text { Source of } \\
\text { variation }\end{array}$ & DF & Plant height & $\begin{array}{c}\text { Branches } \\
\text { plant }^{-1}\end{array}$ & $\begin{array}{c}\text { Capsules } \\
\text { plant }^{-1}\end{array}$ & $\begin{array}{c}\text { Seed } \\
\text { capsules }^{-1}\end{array}$ & $\begin{array}{l}\text { Seed weight } \\
\text { plant }^{-1}\end{array}$ & Seed index & $\begin{array}{c}\text { Biological } \\
\text { yield }\end{array}$ & Seed yield & HI \\
\hline $\begin{array}{c}\text { Planting } \\
\text { geometry (P) }\end{array}$ & 2 & ** & ** & NS & ** & * & ** & ** & $* *$ & $* *$ \\
\hline $\begin{array}{l}\text { Irrigation } \\
\text { regimes (I) }\end{array}$ & 2 & ** & $* *$ & $* *$ & $* *$ & ** & $* *$ & $* *$ & $* *$ & $* *$ \\
\hline $\mathbf{P} \times \mathbf{I}$ & 4 & ** & * & NS & NS & NS & NS & NS & NS & NS \\
\hline
\end{tabular}

Notes: NS, non-significant; ${ }^{*}$ and ${ }^{* *}$, significant at the 0.05 and 0.01 levels of probability, respectively. 


\section{Conclusion}

The results concluded that growth and yield attributes particularly seed yield of sesame was significantly $(\mathrm{P}<$ 0.05 ) affected by all the levels of planting geometry and irrigation regimes. Planting geometry of $45 \times 15 \mathrm{~cm}$ produced maximum parameters, particularly seed yield $\left(742.33 \mathrm{~kg} \cdot \mathrm{ha}^{-1}\right)$. Among irrigation regimes, four irrigations (20, 40, 60 and 80 DAS) recorded highest traits, particularly seed yield (748.78 $\left.\mathrm{kg} \cdot \mathrm{ha}^{-1}\right)$. In case of interaction, planting geometry $45 \times 15 \mathrm{~cm} \times$ four irrigations (20,40, 60 and 80 DAS) resulted in greatest values, particularly seed yield $\left(765.00 \mathrm{~kg} \cdot \mathrm{ha}^{-1}\right)$.

\section{Acknowledgements}

The author (A N) is highly grateful to Professor, Dr. Shamsuddin Tunio, Sindh Agriculture University, Tandojam and Shahab-u-din, Scientific officer, Livestock Research Institute Turbat for their technical support throughout the research work.

\section{References}

[1] Toan, D.P., Thuy-Duong, T.N.A., Carlsson, S. and Bui, T.M. (2010) Morphological Evaluation of Sesame (Sesamum indicum L.) Varieties from Different Origins. Australian Journal of Crop Science, 4, 498-504.

[2] Pakissan.com (2010) Sesame Production Practices in Pakistan. http://www.pakissan.com/english/allabout/crop/sesame.shtml

[3] Khan, M.H.A., Sultana, N.A., Islam, M.N. and Zaman, M.H. (2009) Yield and Yield Contributing Characters of Sesame as Affected by Different Management Practices. American-Eurasian Journal of Scientific Research, 4, 195-197.

[4] Jefferson, T. (2003) Sesame a High Value Oil Seed. Growing Sesame Production Tips, Economics and Mare. Htm, $1-4$.

[5] Wikipedia (2007) Sesame: From Wikipedia, the Free Encyclopedia Wikimedia Foundation, Inc.

[6] GOP (2010) Government of Pakistan, Ministry of Food, Agriculture and Livestock, Finance Division, Economic Advisor Wing, Islamabad Pakistan. 23.

[7] Saleem, M.F., Ma, B.L., Malik, M.A., Cheema, M.A. and Wahid, M.A. (2008) Yield and Quality Response of Sesame (Sesamum indicum L.) to Irrigation Frequencies and Planting Patterns. Canadian Journal of Plant Science, 88, 101-109. http://dx.doi.org/10.4141/CJPS07052

[8] Ashri, A. (1998) Sesame Breeding. Plant Breeding Reviews, 16, 179-228. http://dx.doi.org/10.1002/9780470650110.ch5

[9] Mahdi, A., Amin, S.E.M. and Ahmed, F.G. (2007) Effect of Sowing Date on the Performance of Sesame (Sesamum indicum L.) Genotypes under Irrigation Conditions in Northern Sudan. African Crop Sciences Conference Proceedings, 8 , 1943-1946.

[10] Adebisi, M.A. (2004) Variation, Stability and Correlation Studies in Seed Quality and Yield of Sesame (Sesamum indicum L.). Ph.D. Thesis, University of Agriculture, Abeokuta.

[11] Mahan, R.K.S., Singh, U.P. and Verma, N.K. (2008) Effect of Planting Geometries in Relation to Fertilizer Combinations on Growth and Yield of Mustard (Brassica junceacoss) var. "Varuna” under Bundelkhand Region of Uttar Pradesh. http://www.indianjournals.com/ijor.aspx?target=ijor:asd\&volume=28\&issue=2\&article $=024$

[12] Singh, K., Dhaka, R.S. and Fageria, M.S. (2004) Response of Cauliflower (Brassica oleracea var. botrytis L.) Cultivars to Row Spacing and Nitrogen Fertilization. Progressive Horticulture, 36, 171-173.

[13] Wysocki, D. and Sirovatka, N. (2010) Effect of Row Spacing and Seeding Rate on Winter Canola in Semiarid Oregon. Journal of Science, 85, 444-446.

[14] Roy, N., Abdullah, S.M. and Jahan, M.S. (2009) Yield Performance of Sesame (Sesamum indicum L.) Varieties at Varying Levels of Row Spacing. Research Journal of Agriculture \& Biological Sciences, 5, 823-827.

[15] Rahnama, A. and Bakhshandeh, A. (2006) Determination of Optimum Row Spacing and Plant Density for Uni-Branched Sesame in Khuzestan Province. Journal of Agricultural Science and Technology, 8, 25-33.

[16] Tiwari, K.P., Jain, P. and Raghuwanshi, S. (1990) Effect of Sowing Date and Plant Densities on Seed Yield of Sesame Cultivars. Crop Research, 8, 404-406.

[17] Tahir, M., Saeed, U., Ali, A., Hassan, I., Naeem, M., Ibrahim, M., et al. (2012) Optimizing Sowing Date and Row Spacing for Newly Evolved Sesame (Sesamum indicum L.) Variety TH-6. Pakistan Journal of Life \& Social Sciences, 10, 1-4.

[18] Maqsood, M., Ali, A., Aslam, Z., Saeed, M. and Ahmad, S. (2002) Effect of Irrigation and Nitrogen Levels on Grain 
Yield and Quality of Sesame. International Journal of Agriculture \& Biology, 4, 164-165.

[19] Broner, I. (2005) Irrigation Scheduling for Sesame Production. Colorado State University Cooperative Extension, Fort Collins, 1-4.

[20] Hassanzadeh, M., Ebadi, A., Panahyan-e-Kivi, M., Jamaati-e-Somarin, Sh., Sacidi, M. and Gholipouri, A. (2009) Investigation of Water Stress on Yield and Yield Components of Sesame, Sesamum indicum L. in Moghan Region. Research Journal of Environmental Sciences, 3, 239-244. http://dx.doi.org/10.3923/rjes.2009.239.244

[21] Detphirattanamongkhon, S. (2002) Influence of Different Water Regimes and Irrigation Intervals on the Growth and Yield of Sesames. http://agris.fao.org/agris-search/search.do?recordID=TH2001002924

[22] Karaaslan, D., Boydak, E., Gercek, S. and Simsek, M. (2007) Influence of Irrigation Intervals and Row Spacing on Some Yield Components of Sesame Grown in Harran Region. Asian Journal of Plant Sciences, 6, 623-627. http://dx.doi.org/10.3923/ajps.2007.623.627

[23] Caliskan, S., Arslan, M., Arioglu, H. and Isler, N. (2004) Effect of Planting Method and Plant Population on Growth and Yield of Sesame (Sesamum indicum L.) in a Mediterranean Type of Environment. Asian Journal of Plant Sciences, 3, 610-614.

[24] El-Naim, A.M., Elday, E.M. and Ahmed, A.A. (2010) Effect of Plant Density on the Performance of Some Sesame (Sesamum indicum L.) Cultivars under Rain Fed. Research Journal of Agriculture and Biological Sciences, 6, 498-504.

[25] Moghadam, P.R., Poor, G.N., Nabati, J. and Abadi, A.A.M. (2008) Effects of Different Irrigation Intervals and Plant Density on Morphological Characteristics, Grain and Oil Yields of Sesame, Sesamum indicum (L.). Iranian Journal of Field Crops Research, 6, 112-116. 